\title{
PENGARUH PENGGUNAAN PUZZLE JARI TANGAN DALAM MENGEMBANGKAN MOTORIK HALUS DI TAMAN KANAK-KANAK
}

\author{
Satriani $^{1} \&$ Sitti Nur Hidayah Ilyas ${ }^{2}$ \\ Pendidikan Guru Pendidikan Anak Usia Dini, Universitas Negeri Makassar
}

\begin{abstract}
:
One of the games that requires patience and meticulous care in putting together puzzles is a game of arranging picture pieces. Puzzles for children aged 2-4 years have simple shapes with simple pieces or pieces of the puzzle and there are not too many of them. In contrast to puzzles for children aged 4-5 years the number of pieces is more. The purpose of this study was to determine whether there was an effect of finger puzzle playing on fine motor skills in group B children in Al Hasyim Kindergarten. This research uses quantitative research. The research subject is Al Hasyim Kindergarten in group B with 20 students and 2 teachers. The research procedure was carried out in 3 ways, namely tests, observation and documentation. The results of research on children's fine motor skills through finger puzzle activities in Al Hasyim Kindergarten, Biringkanaya District, Makassar City, show that through finger puzzle activities can develop children's fine motor skills. With this puzzle activity, a teacher can know directly and see a picture of the abilities possessed by students.
\end{abstract}

Keywords: Fine motoric, playing hand finger puzzles

\begin{abstract}
Abstrak:
Salah satu permainan yang membutuhkan kesabaran dan teliti dalam menyusun puzzle merupakan permainan menyusun potongan-potongan gambar. Puzzle untuk anak usia 2-4 tahun memiliki bentuk sederhana dengan potongan atau keping puzzle yang sederhana dan jumlahnya tidak terlalu banyak. Berbeda dengan puzzle untuk anak usia 4-5 tahun jumlah kepingannya lebih banyak. Tujuan penelitian ini adalah untuk mengetahui apakah ada pengaruh kegiatan bermain puzzle jari tangan terhadap kemampuan motorik halus pada anak kelompok B di Taman Kanak-kanak Al Hasyim. Penelitian ini menggunakan penelitian kuantitatif. Adapun subjek penelitian yaitu Taman Kanak-kanak Al Hasyim pada kelompok B dengan jumlah anak didik 20 Orang dan 2 guru. Prosedur penelitian ini dilakukan dengan 3 cara yaitu tes, observasi dan dokumentasi. Hasil penelitian mengenai kemampuan motorik halus anak melalui kegiatan puzzle jari tangan di Taman Kanak-kanak Al Hasyim Kecamatan Biringkanaya Kota Makassar menunjukkan bahwa melalui kegiatan puzzle jari tangan dapat mengembangkan motorik halus anak. Dengan kegiatan puzzle tersebut, maka seorang guru dapat mengetahui secara langsung dan melihat gambaran terhadap kemampuan-kemampuan yang dimiliki oleh anak didik.
\end{abstract}

Kata Kunci: Motorik halus, bermain puzzle jari tangan

Artikel dengan akses terbuka dibawah licenci Creative Commons Attribution-NonCommercial 4.0 International License. (https:// creativecommons.org/licenses/by-nc/4.0/). Received: Oktober 2019, Accepted: Nopember 2019, Published: Desember 2019 


\section{PENDAHULUAN}

Pendidikan pada dasarnya diperuntukkan untuk setiap warga negara yang berusaha mengembangkan potensi diri melalui proses pembelajaran yang tersedia pada jalur, jenjang, dan jenis pendidikan tertentu. Pendidikan sangatlah penting, karena dalam pendidikan akan mendapatkan ilmu yang sangat berguna dan berarti bagi kehidupan setiap orang. Pendidikan anak usia dini adalah suatu upaya pembinaan yang ditujukan kepada anak sejak lahir sampai dengan usia enam tahun yang dilakukan melalui pemberian rangsangan pendidikan untuk membantu pertumbuhan dan perkembangan jasmani dan rohani agar anak memiliki kesiapan dalam memasuki pendidikan lebih lanjut.

Usia dini merupakan masa dimana seorang anak berada pada usia emas (golden age), dimana anak sedang dalam tahap pertumbuhan dan perkembangan yang paling pesat baik fisik maupun mentalnya. Pendidikan anak usia dini merupakan wahana pendidikan yang sangat mendasar dalam memberikan kerangka dasar terbentuk dan berkembangnya dasardasar pengetahuan, sikap dan keterampilan pada anak. Keberhasilan proses pendidikan pada masa dini tersebut menjadi dasar untuk proses pendidikan selanjutnya. Menurut Jean Piaget Ada empat periode dalam perkembangan anak yaitu tahap sensori motor (usia 0-2 tahun), Tahap pra-operasional (usia 2-7 tahun), Konkret operasional (usia 7-11 tahun) dan formal operasional (usia 11-15 tahun), Jadi perkembangan kognitif anak usia dini pada usia 2-7 tahun masuk ke dalam tahap pra-operasional, Anak seusia ini masih sangat senang dalam bermain. Agar anak mencapai tahap pencapaian perkembangan yang optimal, Kita sebagai peran guru harus menyediakan alat permainan edukatif atau media yang menarik dan menyenangkan. Sehingga anak senang dalam mengikuti pembelajaran sambil bermain dan tidak mudah bosan.

Bermain bagi anak pasti sangat menyenangkan, Sehingga bila anak diajak ikut bermain pasti anak akan senang dan didalam bermain anak juga dapat sambil belajar. Menurut Dewey (Montolalu,2005:17) Percaya bahwa anak belajar tentang dirinya sendiri serta dunianya melalui berm ain. Melalui pengalaman-pengalaman awal bermain yang bermakna menggunakan benda-benda konkret, Anak mengembangkan kemampuan dan pengertian dalam memecahkan masalah, Sedangkan perkembangan sosialnya meningkat melalui interksi dengan teman sebaya dalam bermain. Bermain dapat mengajarkan anak menyesuaikan diri dengan teman-teman yang ada di lingkungannya. Teori bermain ini sangat penting dalam menunjang main anak, dan menjadi acuan dalam menentukan tahap perkembangan anak, baik dari segi afeksi, kognitif, motorik, bahasa maupun sosial emosional. Jadi, pengertian bermain diatas dapat disimpulkan bahwa bermain adalah dunia anak-anak, Yang merupakan hak asasi bagi anak usia dini untuk mengembangkan kemampuan dan pengertian dalam memecahkan masalah. Bermain dapat melatih perkembangan anak, baik dari segi motorik, bahasa, sosial emosional dan kognitif.

Bermain sangat bermanfaat bagi perkembangan otak anak. Bermain yang melatih penglihatan dan motorik halus anak seperti bermain puzzle. Dalam bermain puzzle anak dapat memahami bentuk dan ukuran mana yang tepat untuk disatukan dengan potongan lainnya. Anak akan terlatih untuk memecahkan masalah. Puzzle menawarkan latihan mengagumkan bagi ketangkasan jari dan koordinasi mata tangan, serta konsep motorik mencocokkan bentuk dan hubungan bagian dengan keutuhan. 
Anak akan lebih senang bila diberikan permainan. Puzzle merupakan salah satu permainan yang membutuhkan kesabaran dan teliti dalam menyusun puzzle merupakan permainan menyusun potongan-potongan gambar. Menurut Zaman (2006:57) Puzzle untuk anak usia 2-4 tahun memiliki bentuk sederhana dengan potongan atau keping puzzle yang sederhana dan jumlahnya tidak terlalu banyak. Berbeda dengan puzzle untuk anak usia 4-5 tahun jumlah kepingannya lebih banyak.

Jadi pengertian puzzle diatas dapat disimpulkan bahwa puzzle adalah media bermain yang cara bermainnya seperti menyusun dan mencocokkan potongan-potongan gambar, huruf, bangun-bangun atau angka sehingga disusun menjadi sebuah puzzle yang utuh. Dalam menyusun puzzle maka akan melatih kesabaran, Ketangkasan mata dan tangan untuk menyusun puzzle tersebut. Selain itu kegiatan ini dapat dilakukan melalui bermain agar anak tidak mudah merasa bosan dan menerapakan metode belajar melalui bermain dapat membantu anak dalam belajar sehingga meningkatkan hasil belajar anak menjadi lebih baik.

Berdasarkan hasil observasi di Taman Kanak-kanak Al Hasyim Kecamatan Biringkanaya Kota Makassar menunjukkan kemampuan motorik halus anak masih kurang maksimal. Kemampuan anak dalam menggerakkan dan mengkoordinasikan gerakan tangan dan mata masih kurang. Terlebih pada saat anak membuat suatu hasil karya, Anak terlihat masih kaku dalam menggerakkan jari-jari tangannya sehingga hasil karya yang dibuat tidak rapi dan menarik. Selain itu, Kegiatan di kelas juga lebih berfokus pada hasil yakni anak sudah melaksanakan tugas atau belum dan bukan proses bagaimana anak dapat menyelesaikan satu cara menyenangkan bagi anak membuat anak berproses dalam mengerjakannya serta dapat meningkatkan kemampuan motorik halus anak.

Salah satu pengembangan motorik halus anak sangat penting, sebab dengan mengembangkan kemampuan motorik halus anak mampu mengfungsikan otot-otot kecil seperti gerakan jari tangan, mengkoordinasikan kecepatan tangan dan mata dan mampu mengendalikan emosi. Salah satu kegiatan yang dapat mengembangkan motorik halus yaitu media puzzle jari tangan. Dengan bermain puzzle jari tangan membuat jari-jari tangan anak dapat terkoordinasi dengan mata karena anak menggunakan jari-jari untuk melakukan berbagai kegiatan tangan yakni mengambil potongan puzzle dan menyusun potongan puzzle.

\section{METODOLOGI}

Pendekatan yang digunakan pada penelitian ini adalah pendekatan penelitian kuantitatif, yaitu penelitian yang dilakukan untuk menganalisis pengaruh metode alat permainan edukatif puzzle jari untuk menigkatkan perkembangan motorik halus anak usia dini di Taman Kanak-Kanak Al Hasyim Kecamatan Biringkanaya Kota Makassar. Jenis penelitian yang digunakan dalam penelitian ini adalah desain eksperimental semu atau Quasi Experimental Design. Jenis penelitian ini membandingkan kelompok untuk menyimpulkan perubahan yang disebabkan oleh perlakuan (treatment). Desain penelitian yang digunakan yaitu Nonequivalent Control Group Design. Dimana pengukuran dilakukan melibatkan dua kelompok yakni kelompok eksperimen dan kelompok kontrol di mana kelompok tersebut dipilih dan ditempatkan tanpa melalui randomisasi. 
Populasi adalah wilayah generalisasi yang terdiri atas objek/subjek yang mempunyai kualitas dan karakteristik tertentu yang ditetapkan oleh peneliti untuk dipelajari dan kemudian ditarik kesimpulannya. Populasi dalam penelitian ini adalah seluruh kelompok B di Taman Kanak-kanak Al Hasyim Kecamatan Biringkanaya Kota Makassar yang berjumlah 20 anak. Pengambilan sampel dalam penelitian ini dilakukan dengan teknik purposive Sampling (sampling pertimbangan) yaitu teknik pengambilan sampel yang anggota sampelnya dipilih secara sengaja atau dasar dan/atau tujuan tertentu. Sampel yang digunakan pada penelitian ini adalah Sampel yang digunakan dalam penelitian ini adalah kelompok B di Taman Kanak-Kanak Al Hasyim Kota Makassar. Adapun sampel yang diambil yaitu 20 anak terbagi menjadi 10 anak sebagai kelas eksperimen dan 10 anak sebagai kelas kontrol. Data yang diperoleh sebelum dan setelah penggunaan metode puzzle jari tangan, puzzle angka, meremas kertas dan menjiblak jari tangannya. dianalisis menggunakan teknik analisis statistik deskriptif dan uji statistik nonparametrik uji beda (uji wilcoxon signed ronk test).

\section{HASIL DAN PEMBAHASAN}

Dari tes kemampuan motorik halus anak diperoleh data kemampuan motorik halus sesaui dengan yang diberikan dalam penelitian tersiri dari motorik halusyang mengikuti pembelajaran metode puzzle jari tangan, puzzle angka, meremas kertas dan menjiblak jari tangan dan data kemampuan motorik halus kelompok anak yang mengikuti pembelajaran menggunakan media puzzle jari tangan. Berdasarkan perlakuan yang diberikan dalam penelitian ini maka data yang diperoleh terdiri dari : (1) data kemampuan motorik halus anak yang mengikuti pembelajaran metode alat permainan edukatif puzzle jari tangan dengan media puzzle angka,(2) data kemampuan motorik halus anak yang mengikuti pembelajaran mengikuti bermain puzzle jari tangan, meremas kertas, menjiblak jari dan puzzle angka.

\section{Hasil Deskriptif Pretest Kelas Kontrol}

Data yang di kumpulkan mengenai hasil pretest kemampuan motorik halus anak kelas kontrol dengan kegiatan bermain puzzle jari tangan diperoleh nilai terkecil 14 dan nilai terbesar 20. Dari data tersebut di peroleh nilai rata-rata 16,7 dan standar deviasi sebesar 1. Pengategorian data kemampuan motorik halus anak meliputi kategori belum berkembang $(\mathrm{BB})$, mulai berkembang $(\mathrm{MB})$, berkembang sesuai harapan $(\mathrm{BSH})$, dan berkembang sangat baik (BSB). Distribusi pengategorian kemampuan motorik halus anak sebelum di berikan perlakuan berupa kegiatan bermain puzzle jari tangan dapat di lihat dari tabel berikut.

Tabel 4.1 kategori kemampuan motorik halus anak pretest kelas kontrol

\begin{tabular}{llcc}
\hline Interval & \multicolumn{1}{c}{ Kategori } & Frekuensi & Persentase \\
\hline $18,5-20,0$ & Berkembang sangat baik & 3 & $30 \%$ \\
\hline $16,9-18,4$ & Berkembang sesuai harapan & 1 & $10 \%$ \\
\hline $15,3-16,8$ & Mulai berkembang & 2 & $20 \%$ \\
\hline $13,7-15,2$ & Belum berkembang & 4 & $40 \%$ \\
\hline \multicolumn{4}{c}{ Jumlah } \\
\hline
\end{tabular}


Berdasarkan tabel di atas dapat di ketahui bahwa dari 10 jumlah anak yang di jadikan sebagai kelas kontrol terdapat 3 anak dengan persentase 30\% yang dapat berpikir cepat untuk membuat media secara mandiri, dapat membuat media yang unik tepat waktu, dapat memfungsikan jari-jarinya dengan baik, dapat membuat suatu bentuk dengan rapi serta tidak membantu temannya yang belum selesai sehingga berada pada kategori berkembang sangat baik (BSB). Terdapat 1 anak dengan persentase 10\% yang dapat berpikir cepat untuk menyelesaikan puzzle jari tangan secara mandiri dan menyelesaikan medianya tepat waktu sehingga berada pada kategori berkembang sesuai harapan (BSH), terdapat 2 anak dengan persentse $20 \%$ yang dapat menyelesaikan medianya tepat waktu tetapi masih harus di ingatkan untuk membuat media yang bagus oleh guru sehingga berada pada kategori mulai berkembang (MB), dan 4 anak dengan persentase $40 \%$ saat menyelesaikan puzzle jari tangan anak masih di bantu oleh guru dan tidak dapat menyelesaikan medianya tepat waktu sehingga berada pada kategori belum berkembang (BB). Dengan demikian kemampuan motorik halus anak kelas eksperimen sebelum di berikan perlakuan berupa kegiatan bermain puzzle jari tangan menunjukkan bahwa dari 10 anak terdapat $30 \%$ berada pada kategori BSB, $10 \%$ berada pada kategori $\mathrm{BSH}, 50 \%$ berada pada kategori $\mathrm{MB}$, dan $10 \%$ berada pada kategori BB.

\section{Hasil Deskriptif Pretest Kelas Eksperimen}

Data yang di kumpulkan mengenai hasil pretest kemampuan motorik halus anak kelas eksperimen dengan kegiatan bermain puzzle jari tangan diperoleh nilai terkecil 18 dan nilai terbesar 24. Dari data tersebut di peroleh nilai rata-rata 20,8 dan standar deviasi sebesar 1. Pengategorian data kemampuan motorik halus anak meliputi kategori belum berkembang (BB), mulai berkembang (MB), berkembang sesuai harapan (BSH), dan berkembang sangat baik (BSB). Distribusi pengategorian kemampuan motorik halus anak sebelum di berikan perlakuan berupa kegiatan bermain puzzle jari tangan dapat di lihat dari tabel berikut:

Tabel 4.2 kategori kemampuan motorik halus anak pretest kelas eksperimen.

\begin{tabular}{llcc}
\hline Interval & \multicolumn{1}{c}{ Kategori } & Frekuensi & Persentase \\
\hline $18,5-20,0$ & Berkembang sangat baik & 3 & $30 \%$ \\
\hline $16,9-18,4$ & Berkembang sesuai harapan & 1 & $10 \%$ \\
\hline $15,3-16,8$ & Mulai berkembang & 2 & $20 \%$ \\
\hline $13,7-15,2$ & Belum berkembang & 4 & $40 \%$ \\
\hline \multicolumn{4}{c}{ Jumlah } \\
\hline
\end{tabular}

Berdasarkan tabel di atas dapat di ketahui bahwa kemampuan anak pada kelas eksperimen sama dengan kemampuan anak pada kelas kontrol.

\section{Hasil Deskriptif Posttest Kelas Kontrol}

Setelah peneliti memberikan perlakuan berupa kegiatan bermain puzzle jari tangan pada kelas kontrol, selanjutnya peneliti memberikan posttest kepada seluruh subjek penelitian. Data yang di kumpulkan mengenai hasil posttest kemampuan motorik halus anak di peroleh nilai terkecil 17 dan nilai terbesar 23. Dari data tersebut di peroleh nilai rata-rata 20 dan standar deviasi sebesar 1. Distribusi pengategorian kemampuan motorik 
halus anak sebelum di berikan perlakuan berupa kegiatan bermain puzzle jari tangan dapat di lihat dari tabel berikut.

Tabel 4.3 kategori motorik halus anak posttest kelas kontrol

\begin{tabular}{llcc}
\hline Interval & \multicolumn{1}{c}{ Kategori } & Frekuensi & Persentase \\
\hline $18,5-20,0$ & Berkembang sangat baik & 2 & $20 \%$ \\
\hline $16,9-18,4$ & Berkembang sesuai harapan & 3 & $30 \%$ \\
\hline $15,3-16,8$ & Mulai berkembang & 3 & $30 \%$ \\
\hline $13,7-15,2$ & Belum berkembang & 2 & $20 \%$ \\
\hline \multicolumn{4}{c}{ Jumlah } \\
\hline
\end{tabular}

Berdasarkan tabel di atas dapat di ketahui bahwa dari 10 jumlah anak yang di jadikan sebagai kelas kontrol terdapat 2 anak dengan persentase 20\% yang dapat berpikir cepat untuk membuat media secara mandiri, dapat membuat media yang unik tepat waktu, dapat memfungsikan jari-jarinya dengan baik, dapat membuat suatu bentuk dengan rapi serta tidak membantu temannya yang belum selesai sehingga berada pada kategori berkembang sangat baik (BSB). Terdapat 3 anak dengan persentase 30\% yang dapat berpikir cepat untuk menyelesaikan puzzle secara mandiri dan menyelesaikan medianya tepat waktu dehingga berada pada kategori berkembang sesuai harapan (BSH), terdapat 3 anak dengan persentse $30 \%$ yang dapat menyelesaikan medianya tepat waktu tetapi masih harus di ingatkan untuk menyelesaikan puzzle yang bagus oleh guru sehingga berada pada kategori mulai berkembang (MB), dan 2 anak dengan persentase $20 \%$ saat menyelesaikan puzzle anak masih di bantu oleh guru dan tidak dapat menyelesaikan medianya tepat waktu sehingga berada pada kategori belum berkembang (BB). Dengan demikian kemampuan motorik halus anak kelas eksperimen sebelum di berikan perlakuan berupa kegiatan bermain puzzle jari tangan menunjukkan bahwa dari 10 anak terdapat $20 \%$ berada pada kategori BSB, $30 \%$ berada pada kategori $\mathrm{BSH}, 30 \%$ berada pada kategori $\mathrm{MB}$, dan $20 \%$ berada pada kategori BB.

\section{Hasil Deskriptif Posttest Kelas Eksperimen}

Setelah peneliti memberikan perlakuan berupa kegiatan bermain puzzle jari tangan pada kelas eksperimen, selanjutnya peneliti memberikan posttest kepada seluruh subjek penelitian. Data yang di kumpulkan mengenai hasil posttest kemampuan motorik halus anak di peroleh nilai terkecil 18 dan nilai terbesar 24. Dari data tersebut di peroleh nilai rata-rata 20,8 dan standar deviasi sebesar 1. Distribusi pengategorian kemampuan kreativitas anak setelah diberikan perlakuan berupa penggunaan kartu katabergambar dapat di lihat dari tabel berikut.

Tabel 4.4 kategori kemampuan motorik halus anak posttest kelas eksperimen

\begin{tabular}{llcc}
\hline Interval & \multicolumn{1}{c}{ Kategori } & Frekuensi & Persentase \\
\hline $18,5-20,0$ & Berkembang sangat baik & 3 & $30 \%$ \\
\hline $16,9-18,4$ & Berkembang sesuai harapan & 4 & $40 \%$ \\
\hline $15,3-16,8$ & Mulai berkembang & 2 & $20 \%$ \\
\hline $13,7-15,2$ & Belum berkembang & 1 & $10 \%$ \\
\hline \multicolumn{4}{c}{ Jumlah } \\
\hline
\end{tabular}


Berdasarkan tabel di atas dapat di ketahui bahwa dari 10 jumlah anak yang di jadikan sebagai kelas eksperimen terdapat 3 anak dengan persentase 30\% yang dapat berpikir cepat untuk membuat media secara mandiri, dapat menyusun puzzle jari tangan yang tepat waktu, dapat memfungsikan jari-jarinya dengan baik, dapat membuat suatu bentuk dengan rapi serta tidak membantu temannya yang belum selesai sehingga berada pada kategori berkembang sangat baik (BSB). Terdapat 4 anak dengan persentase $40 \%$ yang dapat berpikir cepat untuk menyusun puzzle jari tangan secara mandiri dan menyelesaikan medianya tepat waktu sehingga berada pada kategori berkembang sesuai harapan (BSH), terdapat 2 anak dengan persentse $20 \%$ yang dapat menyelesaikan medianya tepat waktu tetapi masih harus di ingatkan untuk membuat media yang bagus oleh guru sehingga berada pada kategori mulai berkembang (MB), dan 1 anak dengan persentase $10 \%$ saat menyusun puzzle jari tangan anak masih di bantu oleh guru dan tidak dapat menyelesaikan medianya tepat waktu sehingga berada pada kategori belum berkembang (BB).

Hasil penelitian yang diperoleh berdasarkan data dari hasil observasi awal dan akhir, maka dapat diketahui bahwa pegaruh metode alat permainan edukatif puzzle jari tangan kelas eksperimen terhadap kemampuan motorik halus anak setelah dilakukan uji hipotesis dengan analisis uji Wilcoxon. Dalam pengambilan keputusan jika Thitung $<$ Ttabel $=\mathrm{H} 0$ di terima dan $\mathrm{H} 1$ ditolak artinya tidak ada pegaruh metode alat permainan edukatif puzzle jari tangan terhadap kemampuan motorik halus anak anak di kelas eksperimen Taman Kanak-Kanak Al Hasyim Kecamatan Biringkanaya Kota Makassar. Jika Thitung > Ttabel = H0 ditolak $\mathrm{H} 1$ di terima artinya ada pegaruh metode alat permainan edukatif puzzle jari tangan kelas eksperimen terhadap kemampuan motorik halus anak di kelas eksperimen Taman Kanak-Kanak Al Hasyim Kecamatan Biringkanaya Kota Makassar. Jika Zhitung < Ztabel $=\mathrm{H} 0$ di terima dan $\mathrm{H} 1$ ditolak artinya tidak ada pegaruh metode alat permainan edukatif puzzle jari tangan kelas eksperimen terhadap kemampuan motorik halus anak di kelas Eksperimen Taman Kanak-Kanak Al Hasyim Kecamatan Biringkanaya Kota Makassar. Jika Zhitung $>$ Ztabel $=\mathrm{H} 0$ ditolak $\mathrm{H} 1$ diterima artinya ada pengaruh kegitan bermain paralel dengan pegaruh metode alat permainan edukatif puzzle jari tangan kelas eksperimen terhadap kemampuan motorik halus anak di kelas Eksperimen Taman KanakKanak Al Hasyim Kecamatan Biringkanaya Kota Makassar.

Adapun nilai Thitung yang di peroleh yaitu 55 dan Ttabel yaitu 8 maka di peroleh hasil Thitung (55) > Ttabel $=\mathrm{H} 1$ diterima dan $\mathrm{H} 0$ ditolak artinya ada pegaruh metode alat permainan edukatif puzzle jari tangan kelas eksperimen terhadap kemampuan motorik halus anak. Sedangkan nilai Zhitung yang di peroleh yaitu 2,81 dan Ztabel yaitu 1,645 maka di peroleh Zhitung $(2,81)>$ Ztabel $(1,645)=\mathrm{H} 0$ ditolak H1 diterima artinya ada pegaruh metode alat permainan edukatif puzzle jari tangan kelas eksperimen terhadap kemampuan motorik halus anak. Hasil ini menunjukkan bahwa terjadi perubahan nilai terhadap kemampuan motorik halus anak sebelum dan sesudah mendapatkan pembembelajaran berdasarkan kegiatan bermain puzzle jari tangan. Hal tersebut menunjukkan bahwa kemampuan motorik halus anak yang menerima perlakuan berupa kegiatan bermain puzzle jari tangan lebih baik dibanding sebelum diberi perlakuan. Berdasarkan uraian di atas, maka dapat disimpulkan bahwa penerapan kegiatan bermain puzzle jari tangan berpengaruh terhadap kemampuan motorik halus anak. Berdasarkan hasil perhitungan uji wilcoxon terdapat perbedaan yang signifikan antara kemampuan motorik halus anak yang mengikuti kegiatan bermain puzzle jari tangan dengan anak yang mengikuti pembelajaran menggunakan kertas yaitu meremas kertas, menjiblak jari tangan 
dan puzzle angka. Dalam hal ini, rata-rata hasil skor kemampuan motorik halus anak yang mengikuti kegiatan bermain puzzle jari tangan lebih tinggi dibandingkan dengan rata-rata hasil skor kemampuan motorik halus anak yang mengikuti pembelajaran menggunakan kertas yaitu meremas kertas, menjiblak jari tangan dan puzzle angka. Hal ini disebabkan karena kegiatan bermain puzzle jari tangan dapat mempermudah proses pembelajaran di sekolah serta tidak memberatkan beberapa pihak seperti guru dan orangtua murid dikarenakan bahan kertas dan sterofoam mudah untuk di dapat serta memerlukan biaya tidak banyak, pembelajaran dengan media puzzle jari dapat membuat anak lebih bersemangat karna anak dapat terlibat langsung dalam pembuatan media, dari sinilah anak dapat mengeluarkan imajinasinya serta berfikir cepat dan lebih berkonsentrasi dalam membuat media sehingga dapat meningkatkan motorik halus anak. Dari media puzzle anak dapat mengenal dan mengetahui macam jari yang tertinggi dan terendah serta mengenal tangan kanan dan kiri anak, serta dapat mengembangkan kemampuan motorik halus anak yaitu dengan kegiatan bermain puzzle jari tangan yang telah di sediakan dan meningkatkan minat anak untuk berkreasi.

Puzzle menurut astuti (2016:52), "adalah konsep permainan menyusun gambar secara benar, dengan melihat bentuk, warna, dan ukuran". Inti permainan puzzle mengandalkan insting atau kecerdasan spasial dalam melakukannya, dengan cara membongkar dan memasang ulang dalam kesesuaian bentuk, pola atau warna. Dalam penelitian ini, adapun kegiatan yang diberikan dijelaskan dalam skenario pembelajaran yang telah di buat. Kegiatan tersebut antara lain pertama-tama guru menyampaikan dan menjelaskan tentang tema pembelajran. selanjutnya menyampaikan bahwa akan dilakukan kegiatan bermain puzzle jari tangan. Namun, sebelum bermain, terlebih dahulu mempersiapkan anak dengan mengatur tempat duduk anak. Setelah anak duduk, guru memperlihatkan dan menjelaskan cara bermain puzzle jari tangannya. kemudian anak mulai bermain dan membuat apapun sesuai tema. Setelah karya anak sudah jadi, dilakukan tanya jawab tentang perasaan anak mengenai kegiatan bermain puzzle jari tangan. Selanjutnya, dilakukan pembagian kertas untuk menjiblak jarinya. Peran guru sebagai pendidik dalam kegiatan ini adalah mengarahkan anak untuk memahami karya yang telah di buat dan mengajak anak menyebutkan nama-nama jari tersebut, misalnya jari jempol, manis, telunjuk dan sebagainya.

Kegiatan bermain puzzle jari tangan menunjukkan bahwa anak sangat suka dengan permainan tersebut karena dapat bermain langsung dengan teman-temannya, kegiatan ini juga meningkatkan rasa ingin tahu anak yang sangat membantu mengembangkan setiap potensi dalam diri untuk mengembangkan aspek-aspek perkembanganan baik nilai agama dan miral, fisik motorik, kognitif, bahasa, seni, maupun sosial emosional. Sementara pada pembelajaran menggunakan kertas, meremas kertas, puzzle angka dan menjiplak jari tangan, anak terlihat biasa saja dikarenakan kegiatan tersebut sudah biasa dilakukan sehingga anak kurang berekspresi dan kurang memperhatikan dalam hal mengerjakan tugasnya. Dengan demikian dapat diketahui ada perbedaan hal yang menyebabkan perbedaan skor kemampuan motorik halus anak antara kelompok yang mengikuti kegiatan bermain puzzle jari tangan dengan pembelajaran menggunakan kertas, meremas kertas, puzzle angka dan menjiblak jari tangan dimana skor kemampuan motorik halus anak yang mengikuti kegiatan bermain puzzle jari tangan lebih tinggi daripada yang mengikuti pembelajaran menggunakan kertas, meremas kertas, puzzle angka dan menjiplak jari tangan. 


\section{KESIMPULAN}

Gambaran dari kemampuan motorik halus anak berupa kemampuan alat permainan edukatif, meremas kertas menggunakan jari tangan, menjiplak tangan, puzzle angka, dan memasang puzzle jari tangan setelah diberi perlakuan berupa kegiatan bermain puzzle berbeda pada saat sebelum di beri perlakuan. Jumlah anak pada kategori berkembang sesuai harapan dan berkembang sangat baik lebih banyak dibandingkan sebelum diberi perlakuan berupa kegiatan bermain puzzle. Ada pengaruh kegiatan alat permainan edukatif puzzle jari tangan terhadap kemampuan motorik halus pada anak kelompok B di Taman Kanak-kanak Al Hasyim Kecamatan Biringkanaya Kota Makassar.

\section{DAFTAR PUSTAKA}

Arni, Firda. 2014. Kemampuan motorik halus anak dalam kegiatan melipat kertas ditaman kanak-kanak Bhayangkari Panaikang kota makassar, skripsi, Makassar. Fakultas Ilmu Pendidikan UNM. Makassar.

Aisyah, Siti dkk. 2010. Perkembangan dan konsep dasarpengembangan anak. Jakarta: PT Kawan Pustaka.

Arsad.2007. Media Pendidikan dan Penerapannya. Bandung: PT Remaja Karya.

Astuti. 2016. Cara Mudah Asah Otak Anak. Yogyakarta: Penerbit FlashBooks.

Fikriyati, Mirrah. 2013. Perkembangan Anak Usia Emas Golden Age. Laras Media Prima Hamalik, Oemar. 2008. Media Pendidikan. Bandung: PT Citra Aditya Bakti.

Ismail, Andang. 2006. Education Games Menjadi Cerdas dan Ceria dengan Permainan Edukatif. Yogyakarta: Nuansa Aksara

Mujito,2007. Strategi Pengembangan Kreatifitas Pada Anak. Jakarta. Penerbit Kencana. Montolalu, B E F dkk. 2005. Bermain dan Permainan. Jakarta: Universitas Terbuka.

Noorlaila, Ive. 2010. Metode Pengajaran di Taman Kanak-kanak. Jakarta: PT.Rineka Cipta

Sumantri, 2005. Model pengembangan keterampilan Motorik Anak Usia Dini. Jakarta: Depdiknas, Dirjen Dikti.

Sudono. 2000. Sumber Belajar dan alat Permainan. Jakarta: Grasindo.

Soetjinigsih. 2002.Perkembangan Motorik Halus. Jakarta: Erlangga

Peraturan Menteri Pendidikan dan Kebudayaan Republik Indonesia Nomor 137 Tahun 2014. Standar Nasional Pendidikan Anak Usia Dini. Kementrian Pendidikan dan Kebudayaan.

Tahun 2014. Standar Nasional Pendidikan Anak Usia Dini. Kementrian Pendidikan dan Kebudayaan.

Rangkuti, Julia Sarah. 2016. Rumah Main Anak. Yogyakarta: Sahabat Sejati Publishing.

Soebacham, Agustina. 2012. Permainan Asyik Bikin Pintar. Yogyakarta: IN Azna Books.

Sugiyono. 2016. Metode Penelitian Pendidikan Pendekatan Kuantitatif, Kualitatif dan $R \& D$. Bandung: Alfabeta.

Tedjasaputra, Mayke. S. 2001. Bermain, Mainan, dan Permainan Untuk Pendidikan Anak Usia Dini. Jakarta: Grasindo. 
Yudiasmini, Ujianti Agung. 2014. Penerapan Model Pembelajaran Kooperatif Tipe Teams Games Tournament TGT Berbantuan Media Puzzle dalam Meningkatkan Perkembangan Kognitif, (diakses 16 Februari 2017)

Yulianti, Rani. 2008. Permainan yang Meningkatkan Kecerdasan Anak. Jakarta: Laskar Aksara

Zaman, B., Hernawan. 2005. Media dan Sumber Belajar TK. Modul Universitas Terbuka. Jakarta: Pusat Penerbitan Universitas Terbuka.

Zaman, Badru. 2006. Pengembangan Alat Permainan Edukatif Untuk Anak Taman Kanak-kanak. Modul Universitas Terbuka. Jakarta: pusat Penertiban Universitas Terbu 